Review

\title{
BREEDING OF NEW APPLE CULTIVARS IN BELARUS
}

\author{
Zoya Kazlouskaya, Tatyana Hashenka, Vitaly Vaseha, and Sergei Yarmolich
}

Institute for Fruit Growing of the National Academy of Sciences of Belarus,

2 Kovalev Str., Samokhvalovitchy, Minsk region, 223013, BELARUS

Communicated by Edite Kaufmane

The article presented the results of 20 years of the Belarusian apple breeding programmne. Apple breeding has old traditions at the Institute for Fruit Growing in Belarus. Special attention is paid to new adaptive dessert apple cultivars. As a result of the second stage of the durable resistant apple breeding programme, conducted in 1994-2010, six Belarusian apple cultivars were submitted to State Testing of the Republic of Belarus. The cultivars were selected from the apple hybrid fund obtained in 1994-2000. In total, 252 progenies with more than 22300 seedlings were assessed for their susceptibility to scab after artificial inoculation in the nursery, and almost 5000 seedlings were further evaluated for spontaneous infections after natural inoculation in orchards, where they had grown without any chemical spraying against the disease. After evaluation of three cropping seasons, 120 selections were propagated on rootstocks B.62-396 and PB 4. The best selections with combined resistance to fungal diseases and winter frost, high crop yield and attractive fruits were the new cultivars 'Belana', 'Diyament', 'Krasavita', 'Navavita', 'Sakavita' and 'Zorka'.

Key words: apple breeding, molecular identification, new cultivars, resistance to scab, Belarus.

\section{INTRODUCTION}

Apple is the main crop in Belarusian orchards. Currently $70 \%$ of total fruit production is apple. The best crop yield was in 2010, which amounted to 559300 tons of apple fruit. In 2011, 212500 tons were collected, including that from small private gardens. Gross output of commercial orchards was $30 \%$. The level of apple production in Belarus is the same as in the European countries Austria, Switzerland, and United Kingdom. The European fruit industry is presently facing economic challenges imposed by increasingly fierce international competition in the past decade, due to the rapid development of Asia output, in particular China. Moreover, Europe also consumes large quantities of apples, importing them from other regions, including from the southern hemisphere. In this context, the European market has applied quality standards for apples and innovative products are in great demand. During the past 15 years, about one hundred new cultivars have been developed in European institutes. These are generally protected cultivars and the market is still dominated by traditional cultivars (Sansavini, 2013).

The main aim of the Belarusian apple breeding programme is improvement of the domestic market and export, in particular to Russia. Apple cultivars with late ripening form the main assortment of modern commercial orchards. The National Register contains 48 apple cultivars, including 23 cultivars of Belarusian breeding. The most important cultivars are 'Alesya', 'Imant', 'Belorusskoye Sladkoye', 'Vesyalina' and other cultivars of Belarusian breeding, which are adapted to the climate in every region of Belarus. Recently, a large number of cultivars were imported from Poland, such as 'Idared', 'Sampion', 'Jonagold', and 'Ligol'. However, after the last two harsh winters, the interest of growers in the cultivars has rapidly decreased.

Apple breeding has a long tradition in Belarus. The first breeding experiments began in 1929 and have continued up to the present time. As the apple assortment of orchards in the first half of last century was formed by early ripening local and non-adapted late varieties from West Europe and USA, the aim was to create late ripening apples with a long storage life and well adapted cultivars to climatic conditions of Belarus. There are three periods of Belarusian breeding work: 1929-1964 - Syubarov's period, resulting in 17 cultivars, including 'Bananovoye', 'Belorusskii Sinap', and 'Minskoye' etc.; 1964 (1958) - 1992 - Kovalenko's period in which were obtained cvs. 'Belorusskoye Malinovoye', 'Antei', 'Alesya', 'Vesyalina', 'Verbnoye' and others; and the modern period, since 1993. Information on the Belarusian breeding programme and its results has been presented in various publications and at scientific symposia (Syubarov, 1968; Kazlouskaya, 2003, 2006, 2011).

Modern apple breeding aims to produce a new hybrid fund for obtaining commercial cultivars with high quality of fruits, and multiple resistance to various biotic and abiotic 
stresses. There is a strong need for new superior cultivars due to high competition in new orchards. This goal does not differ from the strategic goal of the European breeding programme (Lespinasse, 2009). To generate high efficiency of the fruit breeding programme, the new European FruitBreedomics initiative was set up in 2011 (www. fruitbreedomics.com). This large collaborative project has the strategic goal of improving the efficiency of current fruit breeding programmes by bridging the existing gap between scientific molecular genetics research and application in breeding. From this project, new pre-breeding material will be available and proposed to European public/private companies for creating and releasing varieties that can face the new challenges, such as climatic changes and pesticide bans.

Belarus is outside of the EU, but our Institute has good connections with many research institutes in the world and has a rich apple genetic collection. Thanks to government financial support, there are some collaborative projects with the Institute of Genetic and Cytology of NAS Belarus that are directed to improving understanding of the genetics underlying novel traits and providing phenotypic methods (Urbanovich et al., 2011; Урбанович и др., 2011a; 2011b; 2011c).

\section{CLIMATIC CONDITIONS}

The climate of Belarus is moderate continental, typical of moderate latitudes, flat relief and large distance from the Atlantic Ocean. The vegetation season extends from mid April till October. Total duration of the period with temperature above $+5{ }^{\circ} \mathrm{C}$ is $180-208$ days. The maximum sum of temperatures above $+5{ }^{\circ} \mathrm{C}$ is $2918{ }^{\circ} \mathrm{C}$ and the average is $2517{ }^{\circ} \mathrm{C}$ for the last decade. Annual precipitation sum is on average 500-600 mm and varies from 512 to $864 \mathrm{~mm}$; in the vegetative season the precipitation sum is 247 and 614 $\mathrm{mm}$ for 41 and 88 days, respectively. June average temperature is $18.3-19.0{ }^{\circ} \mathrm{C}$.

In the last 20 years, the central part of Belarus has had unstable winter weather. Winters tended to have frequent and rapid fluctuations of temperatures, with short 10-15 day fall of temperature to $-15 \ldots-20{ }^{\circ} \mathrm{C}$ followed by thaws of $0.3-6$ ${ }^{\circ} \mathrm{C}$ for 13-22 days. Once per decade, temperatures in November can drop to $-24.3{ }^{\circ} \mathrm{C}$. $15-28$ days of temperature around -29 to $-32{ }^{\circ} \mathrm{C}$ can occur once every per five years. Annually, a frost period of -7 to $-13{ }^{\circ} \mathrm{C}$ lasts for $4-8$ days in March, with temperatures falling to $-21 \ldots-25{ }^{\circ} \mathrm{C}$ for $10-13$ days once every five years. Average minimal temperatures range from -26 to $-27{ }^{\circ} \mathrm{C}$ in the eastern part of the southern zone and from -22 to $-26{ }^{\circ} \mathrm{C}$ in the western part. On some days temperature reached -34 to $-37{ }^{\circ} \mathrm{C}$, for example in February 2010 and 2012.

\section{CHARACTERISTIC OF THE APPLE HYBRID FUND}

Not every cultivar can realize its potential in the climate of Belarus. Taking into account the length of the vegetation period, number of solar hours during the vegetation period and cold winters, the breeding programme included more than 100 varieties of different geographic and genetic origin, the best Belarusian cultivars and promising selections, and some best foreign cultivars. The breeding programme is aimed to use favourable characters for breeding high quality cultivars based on a few excellent cultivars and their progenies. Special traits, such as disease resistance, pest resistance and labour-saving characteristics are aimed for in apple cultivars from progenies of the species $M$. prunifolia, M. sieboldii, M. zumi, M. coronaria, M. sargentii, $M$. niedzwetzkyana.

According to our analysis, the cultivar 'Belorusskoye Malinovoye' ('Antonovka' $\times$ 'Lawfam') and its offspring are the most efficient sources in apple breeding in the regional conditions (Kazlouskaya, 2003). Recombination of genes from 'Antonovka' and 'Lawfam' with offspring of the old cultivar 'Babushkino' in new genotypes has allowed to combine high adaptivity with good quality of fruits in hybrid populations.

A new apple hybrid fund was created in 1994-2000 and 2006 in Samokhvalovitchy, Minsk region. Crossing was a chief method of breeding. During this investigation period, the total volume of 1-year-old hybrid plants was 29516 seedlings obtained from more than 170 thousand seeds including 252 progenies. 4938 hybrid plants on own roots in orchards, and 18 selections on rootstocks 62-396, PB.4 ( $16.7 \%$ selections) were planted in the experimental orchard after screening tests on resistance to scab, mildew, canker, frost etc. in nursery (Table 1). The study of trial hybrids and selections was carried out during 1994-2011, according to methods of VNIISPK (Sedov, 1995; 1999). Evaluation of apple tree winter-hardiness was carried out by direct freezing (Kazlouskaya et al., 2008).

Most accessions of our apple collection had poor flowering in 1995 and 1997. Nevertheless, we could select the most frost resistant genotypes as parents for crossing. As a result, a series of selections resistant to frost were derived. From the hybrid fund, 120 promising genotypes were selected, which were further tested in other experimental orchards on

\section{Table 1}

CHARACTERISTICS OF APPLE HYBRID FUND OBTAINED FROM CROSSING IN 1994-2000

\begin{tabular}{l|c|c|c|c|c|c}
\hline Year & $\begin{array}{c}\text { Number of } \\
\text { crosses }\end{array}$ & $\begin{array}{c}\text { Number of } \\
\text { flowers }\end{array}$ & $\begin{array}{c}\text { Number of } \\
\text { seeds }\end{array}$ & $\begin{array}{c}\text { Number of } \\
\text { 1-year old } \\
\text { hybrid } \\
\text { plants }\end{array}$ & $\begin{array}{c}\text { Number of } \\
\text { selection } \\
\text { in orchards }\end{array}$ & $\begin{array}{c}\text { Number of } \\
\text { promising } \\
\text { selections }\end{array}$ \\
\hline 1994 & 42 & 73660 & 19664 & 8755 & 517 & 15 \\
1995 & 10 & 4370 & 2179 & 840 & 117 & 4 \\
1996 & 35 & 65090 & 32652 & 2750 & 603 & 6 \\
1997 & 30 & 19040 & 7929 & 2720 & 330 & 8 \\
1998 & 54 & 59020 & 34453 & 5417 & 1156 & 9 \\
1999 & 47 & 83800 & 53814 & 5244 & 940 & 51 \\
2000 & 48 & $\mathbf{7 9 7 2 0}$ & 19744 & 3790 & 1275 & 31 \\
Total & $\mathbf{2 5 2}$ & $\mathbf{3 8 4} \mathbf{7 0 0}$ & $\mathbf{1 7 0 4 3 5}$ & $\mathbf{2 9 5 1 6}$ & $\mathbf{4 9 3 8}$ & $\mathbf{1 2 0}$
\end{tabular}


dwarf rootstocks 62-396 and PB 4. Ancestors of 85 of them are old cultivars: 'Antonovka', 'Lawfam', 'Babushkino', and 'Pepin Litowskii'.

\section{EVALUATION FOR RESISTANCE TO SCAB}

Disease resistance is an important objective in most apple breeding programmes (Kellerhals, 2009). Apple cultivars need to be able to resist or tolerate scab (Venturia inaequalis). Sources with polygenic scab resistance have been used for a long time in the Belarusian breeding programme. In the second half of $20^{\text {th }}$ century, the $R v 6(V f)$ gene of Malus floribunda 821 was the most used source of scab resistance, and high quality scab-resistant cultivars have been developed during the last 60 years. In the 1990's, scab-resistant sources with the gene $R v 6$ were included in our breeding programme. The most efficient male parent in our breeding programme was the Swedish selection BM41497 (Kazlovskaya et al., 2000). Donor properties of the genotype were reproduced in offspring very well. In the second stage of the apple durable resistance breeding programme, in 1993-2000, promising selections from the cross-combination 'Antei' $\times$ BM41497 were used, along with the resistant cultivars containing gene Rv6: 'Imrus', 'Liberty', 'Sawa', 'Jonafree', 'Freedom', 'Otava' (Table 2). The genotypes were used as female and male parents $\left(F_{1}\right.$ BM41497), some of them as male or female.

Forty promising selections were obtained as a result of using $\mathrm{F}_{1}$ BM41497. Furthermore, three were implemented as cultivars after multiple testing. A low proportion of hybrids with good morphological characters was obtained from genotypes 'Freedom', 'Jonafree', 'Imrus', 'Priscilla', 'Relinda', and 'Reglindis' during selection in the nursery.

Table 2

RESULTS OF APPLE BREEDING USING SCAB RESISTANT SOURCES IN 1994-2000

\begin{tabular}{|c|c|c|c|c|}
\hline Genotype & $\begin{array}{c}\text { Number of } \\
\text { crosses }\end{array}$ & $\begin{array}{c}\text { Number of } \\
\text { selections in } \\
\text { orchard }\end{array}$ & $\begin{array}{l}\text { Number of } \\
\text { promising } \\
\text { selections }\end{array}$ & $\begin{array}{c}\text { Number of } \\
\text { realised } \\
\text { cultivars }\end{array}$ \\
\hline $\mathrm{F}_{1} \mathrm{BM} 41497$ & 18 & 641 & 40 & 3 \\
\hline Freedom & 1 & 43 & 1 & 0 \\
\hline Jonafree & 2 & 79 & 2 & 0 \\
\hline Imrus & 1 & 12 & 1 & 0 \\
\hline Liberty & 6 & 260 & 13 & 1 \\
\hline Otava & 3 & 26 & 7 & 1 \\
\hline Prima & 2 & 83 & 4 & 0 \\
\hline Priscilla & 1 & 7 & 1 & 0 \\
\hline Relinda & 1 & 4 & 1 & 0 \\
\hline Reglindis & 1 & 3 & 1 & 0 \\
\hline Remo & 1 & 20 & 1 & 0 \\
\hline Redkroft* & 3 & 28 & 5 & 0 \\
\hline Sawa* & 3 & 30 & 5 & 0 \\
\hline Total & 43 & 1236 & 82 & 5 \\
\hline
\end{tabular}

* promising selections derived from the same hybrid combiation (Antei $\times$ BM41497)
They were subsequently not included hybridisation. 'Redkroft' and 'Sawa' in crossing with selections from the family 'Antei' x BM41497 gave good results. Sometimes, the number flowers of foreign cultivars was not sufficient. Two cultivars were obtained from the efficient sources 'Liberty' and 'Otava' in combination with Belarusian selections.

Recently, a scab epidemic has been observed annually. In 2004 we observed damage by scab in some $R v 6$-resistant cultivars in our collection orchard, mainly foreign cultivars such as 'Freedom', BM41497, 'Prima', and 'Witos'. A very heavy scab epidemic occurred in two consecutive seasons, 2008 and 2009, which allowed to conduct field assessment of scab damage of hybrid progenies, and to compare field and greenhouse results for the progenies. The level of the infection was higher in 2009. In all progenies there was a low share of resistant offspring in 2009, as climate conditions were very favourable for scab development in that year. The investigations on hybrid plots showed differences in durable resistance between progenies (Fig. 1). The highest resistance to scab was observed for the cross-combinations $M . \times$ domestica $M . \times$ zumi and reciprocal crosses $M . \times$ domestica $(M . \times$ prunifolia $M . \times$ floribunda $)$, M. coronaria M. $\times$ domestica, and M. $\times$ domestica $($ M. $\times$ floribunda M. $\times$ atrosanguinea) (Vaseha, 2011). Thus, we began a pyramiding process for durable resistance to scab, including alternative sources of resistance before the appearance of races of scab virulent to Rv6 (Parisi et al., 1993).

Close collaboration with phytopathologists is essential to develop strategies for durable resistance management. Tested by artificial inoculation from scabbed leaves showed that progenies of $R v 6$-gene cultivars were most resistant. The scab strain collection contains those from leaves BM41497, 'Freedom', 'Syabryna' ('Lobo' $\times$ 'Prima') and another scab susceptible genotypes of $M . \times$ domestica, $M . \times$ floribunda, M. coronaria, M. × atrosanguinea, $M . \times$ prunifolia, and $M$. niedzwetzkyana. Study of intraspecific diversity of Venturia inaequalis (Coock.) Wint. revealed five types of strains according to morphological and cultural features (Hashenka, 2009).

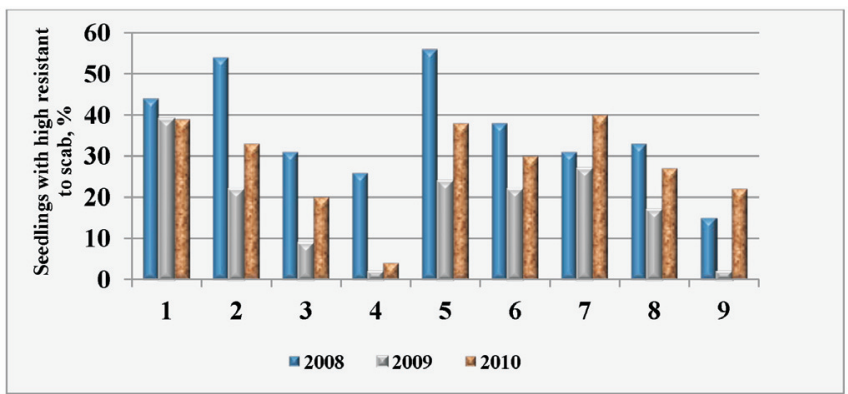

Fig. 1. Hybrid seedlings of apple resistant to scab, depending on genetic origin.

Hybrid populations: $1, M . \times$ domestica $M . \times$ zumi; $2, M . \times$ domestica $(M . \times$ prunifolia $M . \times$ floribunda) ; 3, M. sieboldii $M . \times$ domestica; 4, M. $\times$ domestica M.×domestica; 5, M. coronaria $M . \times$ domestica; $6, M . \times$ domestica $($ M. $\times$ floribunda M. × atrosanguinea) ; 7,M. × zumi M. $\times$ domestica; $8, M . \times$ domestica $M . \times$ floribunda; $9, M . \times$ atrosanguinea $M . \times$ domestica 


\section{IMPLEMENTATION OF MOLECULAR MARKERS}

Selection efficiency can be increased considerably by use of molecular markers (Gianfranceschi et al., 1998). Selecting for disease resistance at an early breeding stage is important, as is juvenility. Recently, many attempts have been made to create new cultivars with multigenic resistance, pyramidised to avoid risk, which has already occurred for the Rv6 gene by breakdown of resistance. Marker-assisted selection for choice of parental lines and to segregate populations have led to improvement of the breeding process. This technique is beginning to find application through the use of various types of molecular markers (SSRs and SNP) associated with the monogenic characteristics we are interested in.

The aim of our study was to investigate the genetic diversity of apple-tree cultivars growing in Belarus and to develop a molecular method of apple genotype identification. SSR-markers have valuable properties including high level of polymorphism, high informativity, reproducibility, and co-dominant inheritance. Due to these properties SSR markers can successfully be used for apple genotype identification (Goulao and Olivera, 2001; Galli et al., 2005; Song et al., 2006; Pereira-Lorenzo et al., 2007).

SSR-markers were applied also for identification of the $R v 6$ gene in hybrid populations. It was revealed that not every hybrid shown to be resistant in testing by artificial inoculation had the Rv6 gene (Hashenka, 2009; Kazlouskaya et al., 2009). The largest share of resistant hybrids without the Rv6 gene was in progenies in which one of parent was derived from 'Antonovka', 'Babushkino', M. sieboldii, or $M$. × zumi. The study revealed a gene Val (Rvil7) in a series of cultivars: old cultivars — 'Antonovka' and 'Korobovka Krupnoplodnaya', Belarusian selections — 'Belorusskii Sinap', 'Charawnitsa', 'Kovalenkovskoye', 'Loshizkoye', 'Novinka Osyeni', 'Pamyat Pashkevitcha', 'Pepin Litowskii Uluchshennyi', 'Verbnoye' and American cv. 'Freedom' (Urbanovich, et al., 2011). However, not all accessions derived from the ancestor 'Antonovka' contains Val, but nevertheless are field resistant to scab, e.g. 'Alesya', 'Shchedroye', 'Pamyat Syubarovoi', and 'Rebristoye'. Many modern cultivars of Belarusian breeding, being progenies of the old local cultivars traditionally grown in this region, are similar to them at the molecular level, e.g. 'Belorusskoye Malinovoye', 'Pepin Litowskii' and its progenies and 'Babushkino' and its progenies.

DNA markers confirmed that BM41497 was the source of the gene $V f$ present in modern cultivars of Belarusian breeding. The cultivars 'Belorusskoe Sladkoe', 'Darunak', 'Nadzeiny', 'Pamyat Kovalenko', and 'Pospeh', which were obtained from BM41497, formed a separate cluster (Urbanovich et al., 2009; Урбанович и др., 2011).

Recently we conducted molecular testing of our initial material and hybrid progenies for identification of some genes providing resistance to scab, mildew, fire blight and aphid (Урбанович и др., 2011). Cv. 'Charawnitsa' ('Belorusskii
Sinap' $\times$ 'Cox's Orange Pippin') has complex resistance to scab, mildew, fire blight and aphid (Urbanovich, et al., 2011), and the old Russian cultivar 'Chulanovka' is an important source of resistance for scab and mildew (Hashenka, 2009; Урбанович и др., 2011). Moreover some offspring of 'Chulanovka' are highly resistant in field, but the genes $P l-1, P l-2, P l-w, P l-d$ were not revealed in their genotypes.

Hence, molecular investigations should be developed for efficient apple breeding.

\section{TEST OF PROMISING SELECTIONS ON DWARF ROOTSTOCKS}

We have been using dwarfing rootstocks 62-396 (Russian breeding) and PB-4 (Belarusian) to shorten selection time and increase breeding efficiency in our environmental conditions. In 2011, complex evaluation of 18 apple selections on these rootstocks was finished. Sixteen selections were obtained from crossing in 1994-1996, and one selection was obtained from crossing in 1987. The comparison of characteristics of the best selections and their pedigree is presented in Tables 3 and 4.

The analysis of pedigree selections indicated their complicated origin. Almost all parents were selections of our earlier apple breeding programme and are characterised as well adapted to our climate conditions. During a period of many years they have been only slightly damaged by frost and disease. Recombination of parental genes has been successful.

All selections are resistant to scab, and maximal damage of leaves was noted as 1 point in 2009, with an average score in 2007-2011 of 0.3-0.8. In our opinion, the most noteworthy is the initial female form 72-11/47 ['Belorusskoye Malinovoye' $\times$ 59-13/9 ('Babushkino $\times$ 'Newtosh')] as a polygenic source of resistance to scab, from which four selections were derived. Three of them, 96-32/9, 96-32/11 and $96-32 / 19$, were obtained from crossing of the genotype with the sensitive cultivar 'Sampion'. These have been little damaged by scab.

All apple promising selections have positive characteristics of fruit, such as appearance, colour, taste and good storage life. Selections 94-23/24, 95-23/43, 95-23/44, and 96-32/11 are very early cropping, and bear fruit in the next year after planting to orchard as one-year old plants. Good average crop yield per tree was obtained from 95-23/43, 95-23/44, and 96-32/11. From these, the cultivars 'Sakavita', 'Navavita' and 'Krasavita' were selected (Yarmolich et al., 2012).

Selections 95-20/34 and 96-29/36 were first tested on rootstock 'PB-4', since they were selected in nursery due to high resistance to diseases and frost before fruit bearing. Later, these selections were propagated on rootstock 62-396 and named 'Belana' and 'Diyament'. 
PEDIGREE, AVERAGE SCORE FOR SCAB AND YIELD OF PROMISING APPLE SELECTIONS (2007-2011)

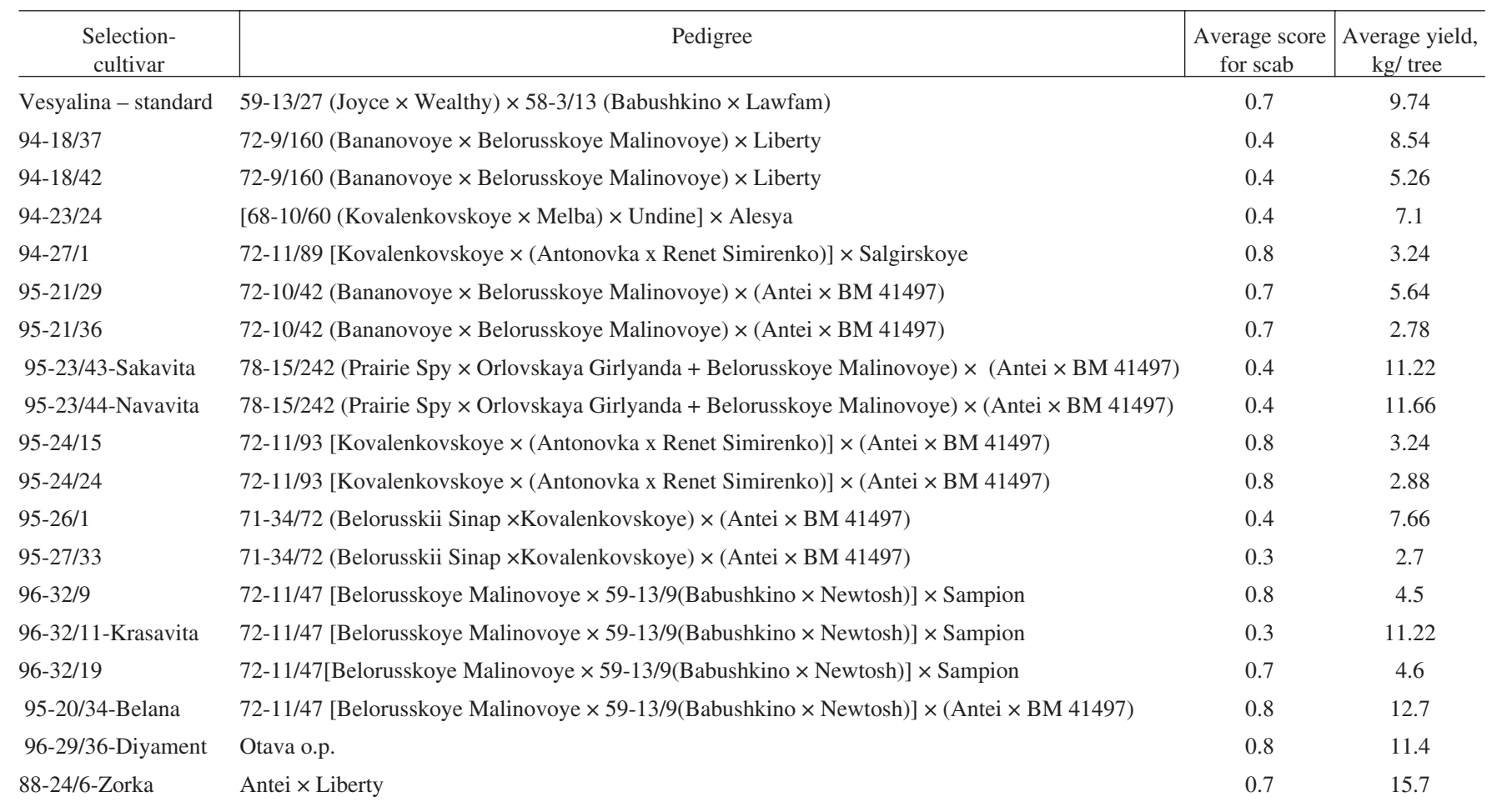

Table 4 FRUIT CHARACTERS OF PROMISING APPLE SELECTIONS

\begin{tabular}{|c|c|c|c|c|c|c|}
\hline Selections, cultivars & $\begin{array}{c}\text { Appearance, points } \\
(1-5)\end{array}$ & Taste, points (1-5) & Weight, g & Index* of shape & Colour ground/over & Storage life, days \\
\hline $94-18 / 37$ & 4.7 & 4.2 & 174 & 0.84 & yellow- green/red & 150 \\
\hline $94-18 / 42$ & 4.0 & 4.2 & 140 & 0.86 & yellow- green/bright red & 170 \\
\hline $94-23 / 24$ & 4.1 & 4.3 & 110 & 0.85 & yellow- green/dark red & 170 \\
\hline $94-27 / 1$ & 4.0 & 4.0 & 105 & 0.76 & green/red-brown & 170 \\
\hline $95-21 / 29$ & 4.5 & 4.2 & 97 & 0.81 & green/purple & 100 \\
\hline $95-21 / 36$ & 4.0 & 4.2 & 105 & 0.84 & green/purple & 140 \\
\hline 95-23/43 - Sakavita & 4.2 & 4.4 & 186 & 0.82 & yellow- green/brown-red & 180 \\
\hline 95-23/44 -Navavita & 4.2 & 4.2 & 150 & 0.76 & whitish green/purple-red & 150 \\
\hline $95-24 / 15$ & 4.3 & 4.1 & 115 & 0.89 & green/purple & 140 \\
\hline $95-24 / 24$ & 4.5 & 4.0 & 136 & 0.94 & yellow- green/dark red & 140 \\
\hline $95-26 / 1$ & 4.5 & 4.0 & 198 & 0.90 & yellow- green/bright red & 170 \\
\hline $95-27 / 33$ & 4.0 & 4.0 & 112 & 0.94 & yellow- green/red-brown & 170 \\
\hline $96-32 / 9$ & 4.3 & 4.5 & 120 & 0.71 & red & 150 \\
\hline 96-32/11 -Krasavita & 4.5 & 4.6 & 150 & 0.82 & yellow /pink- red & 170 \\
\hline $96-32 / 19$ & 4.2 & 4.5 & 173 & 0.73 & yellow/red & 140 \\
\hline 95-20/34 - Belana & 4.4 & 4.5 & 180 & 0.77 & yellow /red & 180 \\
\hline 98-29/36 - Diyament & 4.5 & 4.8 & 158 & 0.75 & yellow/pink-red & 130 \\
\hline 88-24/6 - Zorka & 4.5 & 4.7 & 175 & 0.92 & green/purple red & 150 \\
\hline
\end{tabular}

* Index of shape: $0.90=-$ oblong-conical; $0.80-0.89$ - round; $0.80=$ flat, flat-round

Cv. 'Zorka' originates from the same family as 'Imant', and was tested on different rootstocks in some commercial orchards. In addition, this cultivar was recommended for registration by growers.
Cvs. 'Belana' and 'Diyament' were submitted to State Testing of Belarus in 2009, and the cultivars 'Krasavita', 'Navavita', 'Sakavita', and 'Zorka' in 2011. 


\section{DESCRIPTION OF NEW CULTIVARS}

'Belana' (clone number 95-30/36)

Tree: The growth is semi-vigorous and not too branched. The shape of the crown is rounded with upright branches. Flowering is in the late season and is regular and medium to high every year.

Fruit: Size is medium large, mean weight is $180 \mathrm{~g}$. Base colour is light green at time of picking and yellow when ripe, second colour is red blush on the sun side. Percentage of colour is $15-45 \%$.

Harvest time is at the end of September - beginning of October. Maturity for eating is December till May in traditional storage.

Quality of fruits: The cultivar is an attractive dessert apple for fresh market, taste is very good, sub-acid sweet, flesh is very juicy and sub-firm.

'Diyament' (clone number 96-29/36)

Tree: The growth is slow to medium and moderately branched. The shape of the crown is rounded with semi-upright branches. Flowering begins in the late season and is regular.

Fruit: Size is medium large, mean weight is $158 \mathrm{~g}$. Base colour is light green, second colour is pink-red blush. Percentage of colour is $25-80 \%$.

Harvest time is in the second part of September. Maturity for eating is December till February in traditional storage.

Quality of fruits: The cultivar is an attractive dessert apple for fresh market, taste is good, sub-acid sweet with excellent flavour, flesh is very juicy and medium firm.

'Krasavita' (clone number 96-32/11)

Tree: The growth is slow to medium and moderately branched. The shape of the crown is rounded with upright branches. Flowering begins in the early season and is regular.

Fruit: Size is medium large, mean weight is $150 \mathrm{~g}$. Colour of flesh - yellowish, base colour is yellow-green, second colour is pink red as solid flush with strongly defined stripes.

Harvest time is in the second part of September. Maturity for eating is December till March in traditional storage.

Quality of fruits: The cultivar is an attractive dessert apple for fresh market, taste is good, sub-acid sweet with excellent flavour, flesh is very juicy and medium firm.

'Navavita' (clone number 95-23/44)

Tree: The growth is slow to medium and moderately branched. The shape of the crown is rounded with spreading branches. Flowering begins in the early season and is regular.

Fruit: Size is medium large, mean weight is $150 \mathrm{~g}$. Shape is obloid. Base colour is whitish-green, over colour is purple red with a small relative area of second colour as flushed, narrow striped and mottled. Colour of flesh — greenish.

Harvest time is in the second part of September. Maturity for eating is December till March in traditional storage.

Quality of fruits: The cultivar is an attractive dessert apple for the fresh market, taste is good, acid-sweet with flavour, flesh is very juicy and medium firm.

'Sakavita' (clone number 95-23/43)

Tree: The growth is slow to medium and moderately branched. Habit is spreading. Flowering begins in the average dates and is regular.

Fruit: Size is medium to large, mean weight is $186 \mathrm{~g}$. Shape is globular. Base colour is yellow green, second colour is brown red with small relative area as solid flush with weakly defined stripes. Colour of flesh — greenish.

Harvest time is at the end of September - beginning of October. Maturity for eating is December till May in traditional storage.

Quality of fruits: The cultivar is an attractive dessert apple for fresh market, taste is good, acid-sweet with flavour, flesh is very juicy and medium firm.

'Zorka' (clone number 88-24/6)

Tree: The growth is slow to medium and moderately branched, habit is spreading. Flowering begins in the average dates and is regularly.

Fruit: Size is medium to large, mean weight is $186 \mathrm{~g}$. Shape is conic. Colour of flesh - greenish, base colour is green, second colour is purple red with a large relative area as solid flush with weakly defined stripes.

Harvest time is at the end of September - beginning of October. Maturity for eating is December till May in traditional storage.

Quality of fruits: The cultivar is an attractive dessert apple for fresh market, taste is good, sub-acid-sweet with flavour, flesh is very juicy and medium firm.

\section{CONCLUSIONS}

The new resistant apple cultivars 'Belana', 'Diyament', 'Krasavita', 'Navavita', 'Sakavita', 'Zorka' are well suited to be included into the resistant dessert apple assortment for Belarusian orchards. They combine high fruit quality and resistance against scab, bark canker, winter and spring frosts. They possess a regular high yield. 


\section{REFERENCES}

Galli, Z., Halasz, G., Kiss, E., Heszky, L., Dobranszki, J. (2005). Molecular identification of commercial apple cultivars with microsatellite markers. Hort. Sci., 40, 1974-1977.

Gianfranceschi, L., Seglias, N., Tarchini, R., Komjanc, M., Gessler, C. (1998). Simple sequence repeats for the genetic analysis of apple. Theor. Appl. Genet., 96, 1069-1076.

Goulao, L., Oliveira, C. M. (2001). Molecular characterization of cultivars of apple (Malus domestica Borkh.) using microsatellite (SSR and ISSR) markers. Euphytica, 122, 81-89.

Hashenka, T. A. (2009). The initial material of high-productive apple breeding combining resistance to scab and high fruit quality. Doctoral dissertation, Institute for Fruit Growing, Samokhvalovichy, Belarus. 132 pp. (in Belarusian).

Kazlouskaya, Z. A. (2006). Scientific foundations of apple breeding for commercial orchards in Belarus. Doctoral dissertation, The Belarusian State Agricultural Academy, Gorky, Belarus. 320 pp. (in Belarusian).

Kazlouskaya, Z. A., Marudo, G. M., Ryabtsev, A. S. (2000). Some results of apple breeding programme in Belarus. Acta Hort., 538 (1), 219-224.

Kazlouskaya, Z. A., Yarmolich, S. A., Marudo, G. M. (2008). Method of accelerated evaluation of apple tree winter hardiness with direct freezing use. Fruit-Growing, 20, 265-276.

Kazlouskaya, Z. A., Vaseha, V. V., Hashenka, T. A., Urbanovich, O. Yu. (2009). Effectiveness of applying of different genetic origin initial material in scab-resistance selection. Fruit-Growing, 21, 9-17.

Kellerhals, M., Spuhler, M., Duffy, B., Patocchi, A., Frey, J. E. (2009). Selection efficiency in apple breeding. Acta Hort., 814, 177-184.

Lespinasse, Y. (2009). Review of pome fruit breeding in Europe: Which strategies for the near future? Acta Hort., 814, 865-872.

Parisi, L., Lespinasse, Y., Guillaumes, J., Kruger, J. (1993). A new race of Venturia inaequalis virulent to apples with resistancedue to the $V f$ gene. Phytopatology, 83, 533-537.

Pereira-Lorenzo, S., Ramos-Cabrer, A. M., Diaz-Hernandez, M. B. (2007). Evaluation of genetic identity and variation of local apple cultivars (Malus domestica Borkh.) from Spain using microsatellite markers. Genet. Resour. Crop Evol., 54, 405-420.

Sansavini, S., Tartarini, S. (2013). Advances in apple breeding and genetic control of the main agronomic resistance and fruit quality traits. Acta Hort., 976, 43-55.

Song, Y., Zhai, H., Yao, Y.-X., Li, M., Du, Y.-P. (2006). Analysis of genetic diversity of processing apple varieties. Agr. Sci. China, 5, 745-750.

Urbanovich, O. Yu., Kazlouskaya, Z. A. (2009). Using SSR-markers for identification of apple varieties in Belarus. Acta Hort., 839, 479-486.
Urbanovich, O. Yu., Kazlouskaya, Z. A., Vaseha, V. V., Kuzmickaya, P. V., Kartel, N. A. (2011). Identification of Val among apple cultivars and accessions of genetic origin grown in Belarus. Mol. Appl. Gen. Proc., 12, $56-63$.

Vaseha, V. V. (2011). Realization of the genetic potential of genus Malus Mill. in apple breeding for intensive type cultivars. Doctoral dissertation, Institute for Fruit Growing, Samokhvalovichy, Belarus. 157 pp. (in Belarusian).

Yarmolich, S. A., Kazlouskaya, Z. A., Marudo, G. M. (2012). Comparative estimation of resistence to scab and early maturity potential of Belarusian apple (Malus domestica Borkh.) promising hybrids. Horticulture, 66, 21-28.

Козловская 3. А. (2003). Совериенствование сортимента яблони в Беларуси [Development of Apple Assortment in Belarus]. Минск. 168 c. (in Russian).

Козловская 3. А. (2011). Селекция яблони для интенсивных садов Беларуси [Apple Breeding for Intensive Orchards of Belarus]. LAMBERT Academic Publishing. 390 c. (in Russian).

Седов Е. Н. (1995). Программа и методика селекции плодовых, ягодных и орехоплодньх культур [Programme and Methods of Breeding Fruit, Berry and Nut Crops]. Орел. 502 c. (in Russian).

Седов Е. Н. (1999). Программа и методика сортоизучения плодовых, ягодных и орехоплодньх культур [Programme and methods of variety testing fruit, berry and nut crops]. Орел. 608 с. (in Russian).

Сюбаров А. Э. (1968). Яблоня [The Apple]. Минск: Урожай. 279 с. (in Russian).

Урбанович О. Ю., Козловская 3. А., Картель Н. А. (2011а). Методические рекомендации по идентификации и паспортизации сортов яблони и груши на основе ДНК-маркеров [Methodological Recommendations for Identification and Pasportition of Apple and Pear Cultivars on the Base DNA Markers]. Минск: Право и экономика. 31 c. (in Russian).

Урбанович О. Ю., Козловская 3. А., Картель Н. А. (2011b). Методические рекомендации по идентификации на основе ДНК-маркеров генов устойчивости к парие яблони [Methodological Recommendations for Identification of Apple Scab Resistant Genes on the Base DNA Markers]. Минск: Право и экономика. 32 с. (in Russian).

Урбанович О. Ю., Козловская 3. А., Картель Н. А. (2011с). Методические рекомендации по идентификации на основе ДНК-маркеров генов устойчивости к мучнистой росе яблони [Methodological Recommendations for Identification of Apple Mildew Resistant Genes on the Base DNA Markers]. Минск: Право и экономика. 27 с. (in Russian).

Received 29 November 2012

\section{JAUNU ĀBEḶU ŠḲIRṆU SELEKCIJA BALTKRIEVIJĀ}

Ābeḷu selekcijai Baltkrievijas Aug̣̣kopības institūtā ir senas tradīcijas. Īpaša vērība tiek veltīta, lai veidotu jaunu adaptētu deserta ābolu sortimentu. Stabili rezistentu ābel̦u selekcijas programmas otrā posma rezultātā (1994.-2010. g.) sešas Baltkrievijas selekcijas ābelı šķirnes iesniegtas Valsts škiinnu pārbaudei Baltkrievijā. Škirnes izdalītas no 1994.-2000. g. iegūtā hibrīdu fonda. Kopskaitā vairāk kā 22300 sējeņiem no 252 krustojumiem tika izvērtēta kraupja ieṇēmība pēc mākslīgas inokulācijas izolētā stādaudzētavā un gandrīz 5000 sējeṇi tālāk vērtēti dārzā, lai novērotu spontānu dabisku infekciju, audzējot bez fungicīdu smidzinājumiem. Pēc trīs ražas gadu vērtēšanas 120 elites hibrīdus pavairoja uz potcelmiem B.62-396 un PB 4. Labākās jaunās šḳirnes, kas apvieno izturību pret sēnu slimībām un salu, augstu ražỉbu un pievilcīgus aug̣̣us, ir 'Belana', 'Diyament', 'Krasavita', 'Navavita', 'Sakavita' un 'Zorka'. 